\title{
The Readiness of Secondary Vocational School Graduates to Enter Labor Market
}

\author{
Elih Mulyana ${ }^{a, 1}$, Sumarto ${ }^{a}$, Bachtiar Hasan ${ }^{a}$, Wowo Sunaryo ${ }^{b}$ \\ ${ }^{a}$ Electrical Engineering Education Department \\ ${ }^{b}$ Mechanical Engineering Education Department \\ Indonesia University of Education \\ 1elihmulyana64@gmail.com
}

\begin{abstract}
Secondary Vocational School (SVS) is designed to produce graduates who are ready to work. The observation conducted to some contractors in Bandung West Java, and obtained information about SVS graduates. The information is, they are not ready to work, but they can be trained in order to ready to work. The similar statement also SVS graduates are not ready yet to work in industries or companies. Research on the company has a result that SVS graduates did not satisfaction. The purpose this research to determine the readiness of SVS graduates who will enter labor market. This research used to be explanatory survey method. Data was collected by using instrument, the statement of each instruments item given the option with scale 1 to 5 . The Content of instrument is developed by : intellectual ability, firmness, the spirit (enthusiasm), product-oriented maturity attitudes and behavior, initiative, interpersonal skills, productivity, openness, empowerment ability and technical and then the instrument is distrusted to an electrical contractor in Bandung, West Java. Data analysis using simple statistic, which score in every item instrument is calculated to score maximum, and then calculate the percentage. The results of an assessment of the employees from SVS graduates by electrical contractor shows that SVS graduates in Bandung have high readiness to enter the labor market especially electrical field.
\end{abstract}

Index Terms - readiness, contractor, labor market

\section{Introduction}

Readiness of student to enter in the word of work is all ability that obtainable by training and education. This condition is expected to apply to work in company and industry [1]. The factors that must expected to get a job i.e .[2]:

a. Professional Readiness; Professional preparation is equipping yourself with knowledge, expertise and skills in a particular field. This preparation can be obtained from formal education and lots of practice through apprenticeships and courses to develop the knowledge and skills to become professionals.

b. Preparation attitude and personality; Every profession would needs its own inner attitude that should be obtained and nurtured through education. These attitudes are the responsibility, honesty, reliable, independent, and discipline. In addition, the attitude regarding emotional maturity, feelings, and mind, will the motivation and goals, as well as behavior.

c. Preparations in social field; In the workplace or the world of work, we do not work alone, but in collaboration with others in completing a job. The relationship fellow employee is required to cooperate in the work.

Below are the points that should be considered in job readiness [3] : a. Prospective Employees should have logical reasoning and objective. Have enough maturity, so that the prospective employee has discretion with regard to himself and others.

b. Having the ability and desire to cooperate with others. In the work it takes relationships with many people, so that students are required to interact and collaborate with others.

c. Having Critical Attitudes. Being able to investigate every aspect of the environment and work, give an ideas and initiative.

d. Courage to accept the individual responsibility. Responsibility of the student will appear when the student has reached physical maturity and individual awareness.

e. Have the ability to adapt to the environment. Adjusting to the environment is an asset to interacting the work environment. This capability begins with industry practice experience

f. Having the ambition to move forward and try to follow the development of expertise. The desire to develop is the basis for the emergence of job readiness, with the ambition to advance also give an effort to develop skills according to their expertise, will encouraging students to be better.

g. Response to the job. The response to the work will cause interest to choose the job.

Another explanation of individual readiness criteria will enter the workforce according Hardesky cited by Gibson are [4]:

- Intellectual ability, such as the capacity to thinking logically, practically and analyzed in accordance with the concept.

Assertiveness.

Excitement (enthusiastic).

Results-oriented.

Certain maturity with appropriate attitudes and behaviors.

Initiative, the ability to take over responsibility

- Interpersonal skills.

- Productive.

- Openness.

- Empowerment, a confident attitude.

- Technical, knowledge, skills, behavior, responsibility.

According to the description above can be concluded that the employment readiness for vocational graduates is determined by the will, desire and level of maturity, experience gained, mental and emotional state so that will 
have the ability according to their expertise. SVS aims to promote knowledge, skills and attitude to enter workforce [5]. SVS graduates to be expected have general and special competences to enter the labor market [6]. SVS graduates is expected and they are able to work on Electrical Contractors. The opinion of some electrical contractor director is that vocational graduates not ready to do in the world of work [7].

Based on the observation of the implementation of Competency Test conducted by the certification unit (Institute of Construction Services West Java) and the Association of Electrical and Mechanical professional to 70 vocational high school graduates, the results are as follows:

a. The results of writing test, the assessment scale of 100 is obtained; $80 \%$ of participants scored 40, $10 \%$ scored 50 and $10 \%$ of participants scored 60 .

b. Observations implementation of practice; $60 \%$ Participants are able to use health and safety equipment as much; $70 \%$ Being able to use the appropriate tool functions; $90 \%$ being able to work; 60 $\%$ being able to construct and $50 \%$ have working speed capability according to the time set.

c. Interview Results: Being able to draw $50 \%$; able to read the installation image $50 \%$ and the ability to analyze $30 \%$.

Another statement obtained information that there is a gap between the SVS as labor supply and labor market [8]. In national dialogue, Acceleration the Human Resources Competency Industry, that said, Curriculum of SVS generally had not been design base on National Work Competency Standards (NWCS) [9]. Base on statement in above, this research aims to explore the readiness of graduates of SVS. The information obtained through assessment of electrical contractors in Bandung, West Java.

\section{Methods}

This research used explanatory survey method, research object is the Electrical Contractor in Bandung, West Java. Number of Population is 80 contractor and number of sample can be calculated is 40 [10]. The research is an evaluation of SVS who work in the electrical contractor. Evaluation tools is an instrument that was developed base on the theory intellectual ability, firmness, the spirit (enthusiasm), product oriented maturity attitudes and behavior, initiative, interpersonal skills, productivity, openness, empowerment ability and technical. And then the readiness indicator was developed into 18 item instrument. Based on the validity and reliability of items obtained 11 valid and reliable, then assessment is taken according to the five scale models, a description of assessment scales shown in Table 1 below,

\begin{tabular}{cc}
\multicolumn{2}{c}{ Table 1. Scale model } \\
\hline Description & Scale \\
\hline Very High & 5 \\
High & 4 \\
Fairly High & 3 \\
Low & 2 \\
Very Low & 1 \\
\hline
\end{tabular}

To set criteria for readiness assessment, the data is calculated by statistical approaches, and found the interval length, interval number, and then set the evaluation criteria, calculating the percentage of the maximum and minimum, set the length of the interval and coordinate score interval scale description. The calculation above can be set readiness assessment as follows:

Table 2. Rating Criteria

\begin{tabular}{ll}
\hline Interval & Criteria \\
\hline $86-100$ & Very High \\
$69-85$ & High \\
$52-68$ & Fairly high \\
$35-51$ & Low \\
$18-34$ & Very Low
\end{tabular}

(Source: Field Data, 2014)

\section{Result and Discussion}

The results of each item from instrument electrical contractors assessment then compared with a maximum score of the instrument itself. With the percentage, calculation results on the opinions of the electrical contractors can be classified in the table 2 .

Table 3 Results of Readiness Assessment

\begin{tabular}{lcl}
\hline Item Instrument & $\%$ & Description \\
\hline Intellectual ability & 70 & High \\
Firmness & 65 & Fairly High \\
The spirit (enthusiasm ) & 70 & High \\
Product oriented & 67 & Fairly High \\
Maturity Attitudes and & 66 & Fairly High \\
Behavior & 64 & Fairly High \\
Initiative & 72 & High \\
Interpersonal skills & 69 & High \\
Productivity & 67 & Fairly High \\
Openness , & 70 & High \\
Empowerment ability and & & \\
technical & &
\end{tabular}

(Source: Field Data, 2014)

Readiness is the physically and mentally willingness to perform duties. Job readiness is a prospective workforce readiness to provide education and skills to enter the labor market [8]. Readiness assessment by an electrical contractor to SVS graduates tend to be quite high, with an average percentage of $68 \%$.

\section{Conclusion}

Readiness SVS graduates include professional readiness, preparation and social personality acquired through education in schools. Based on an evaluation by electrical contractor, the readiness of SVS graduates in West Java have high fairly ability to entering in the world of work. Readiness assessment by the electrical contractor actually was not reflect the company's expectations, SVS graduate's competency was not fully applicable to work on electrical contractors. SVS graduates at the first still need training before entering the electrical contractors. And then after 3 to 6 months following the work on the electrical contractors, graduates can do the work according to needs of electric power construction services. So SVS graduates with the provision of education obtained at school, can only be 
categorized ready to trained in the work electrical contractor in West Java. Educational experience at SVS , graduates have the ability to adapt in short time to work in the field, especially employment services, construction of electric power

\section{References}

[1] Harjono (1990) kesiapan memasuki dunia kerja.[online] tersedia: http://wakhinuddin.wordpress.com/2010/page/5/ [ 1 juli 2014]

[2] Mangunhardyana (1988) Seni komunikasi bagi para pemimpin. Yogyakarta: Kanisius

[3] Ana Fitri Yaningsih (2005). Hubungan Motivasi Memasuki Dunia Kerja Siswa kelas XII SMK Mohammadiyah 1 Jatinom Tahun Ajaran 2004/2005. FISE UNY

[4] Gibson et.all (2003). Organization: Behavior, Structure, Processes. Texas: Business Publication

[5] Putu Sudira (2011) Praktis Ideologi Tri Hita Karana dalam Pembudayaan Kompetensi Pada SMK di Bali. Disertasi: Pendidikan Teknologi dan Kejuruan UNY.

[6] Wowo Sunaryo K (2013). Filsafat Teknologi, Vokasi dan Kejuruan..Bandung: Alfabeta

[7] Direktorat PSMK (2010). Dialog Nasional: Percepatan

Komptensi Sumber Daya Manusia Indonesia, Tahun 2010.

[8] Endang S Soesilowati. (2009). Tingkat Kesesuaian Kompetensi Pendidikan

[9] Hartoto Basuki (2011). Dialog Nasional : Percepatan Komptensi Sumber Daya Manusia Indonesia.Jakarta.

[10] Sugiyono (2006). Metode Penelitian Kualitatif Kuantitatif dan R\&D. Bandung: Alfabeta. 